\title{
Gangguan Fungsi Multi Organ pada Bayi Asfiksia Berat
}

\author{
Vera Muna Manoe, Idham Amir
}

\begin{abstract}
Asfiksia perinatal masih merupakan masalah baik di negara berkembang maupun di negara maju dan menyebabkan kematian sebesar $20 \%$ dari bayi baru lahir. Keadaan hipoksia dan iskemia yang terjadi akibat afiksia akan menimbulkan gangguan pada berbagai fungsi organ. Proses terjadinya gangguan bergantung pada berat dan lamanya hipoksia terjadi dan berkaitan dengan proses reoksigenisasi jaringan setelah proses hipoksia tersebut berlangsung. Faktor risiko terjadinya asfiksia pada bayi baru lahir terdiri dari faktor ibu, faktor janin dan faktor persalinan/kelahiran. Hal ini penting, karena dengan pengenalan faktor risiko tersebut maka persiapan resusitasi bayi dapat dilakukan. Beberapa organ tubuh yang akan mengalami disfungsi akibat asfiksia perinatal adalah otak, paru, hati, ginjal, saluran cerna dan sistem darah. Dampak jangka panjang bayi yang mengalami asfiksia berat antara lain ensefalopati hipoksik-iskemik, iskemia miokardial transien, insufisiensi trikuspid, nekrosis miokardium, gagal ginjal akut, nekrosis tubular akut, enterokolitis, SIADH (syndrome inappropriate anti diuretic hormone) kerusakan hati, Koagulasi intra-vaskular diseminata (KID), perdarahan dan edem paru, penyakit membran hialin HMD sekunder dan aspirasi mekonium.
\end{abstract}

Kata kunci: asfiksia, hipoksia, iskemia, ensefalopati, bayi baru lahir.

$C$

sfiksia perinatal masih merupakan penyebab utama morbiditas dan mortalitas pada bayi baru lahir baik di negara berkembang maupun di negara maju. ${ }^{1,2}$ Di negara maju angka kejadian asfiksia berkisar antara 1-1,5\% dan berhubungan dengan masa gestasi dan berat lahir. ${ }^{3}$ Di negara berkembang angka kejadian bayi asfiksia lebih tinggi dibandingkan di negara maju karena pelayanan antenatal yang masih kurang memadai. Sebagian besar bayi asfiksia tersebut tidak memperoleh penanganan yang adekuat sehingga banyak diantaranya meninggal., ${ }^{1,4}$

Dr. Vera Muna Manoe: PPDS Ilmu Kesehatan Anak FKUI, Jakarta

Alamat Korespondensi:

Dr. Idham Amir, SpA.

Subbagian Perinatologi. Bagian Ilmu Kesehatan Anak FKUI-RSCM. Jl. Salemba no.6, Jakarta 10430 .

Telepon: 021-3154020. Fax.: 021-390 7743.
Indonesia mempunyai 200 juta penduduk dengan angka kelahiran 2,5\%/tahun sehingga diperkirakan terdapat 5 juta kelahiran per tahun. Jika angka kejadian asfiksia 3-5\% dari seluruh kelahiran, diperkirakan 250 ribu bayi asfiksia lahir pertahun. ${ }^{4}$ Di Bagian Ilmu Kesehatan Anak FKUI-RSCM pada tahun 2000 didapatkan 6,3\% bayi asfiksia dari seluruh kelahiran, 2,1\% diantaranya lahir dengan asfiksia berat. ${ }^{5}$ Pelbagai faktor pada ibu dan bayi berperan sebagai faktor risiko asfiksia perinatal. ${ }^{6}$ Penilaian perinatal terhadap faktor risiko dan penanganan perinatal yang baik pada kehamilan risiko tinggi sangat mutlak pada asfiksia perinatal. Apabila komplikasi asfiksia sudah terjadi maka diperlukan pendekatan multidisiplin untuk mencegah kerusakan yang sudah terjadi agar tidak bertambah berat. ${ }^{7,8}$

Tulisan ini bertujuan untuk membahas dampak asfiksia pada sistem susunan saraf pusat, jantung, ginjal, gastrointestinal, darah dan paru, sehingga penanganan asfiksia pada bayi baru lahir akan lebih baik. 


\section{Definisi Asfiksia Perinatal}

Asfiksia Perinatal ${ }_{i}$ adalah suatu stres pada janin atau bayi baru lahir karena kurang tersedianya oksigen dan atau kurangnya aliran darah (perfusi) ke berbagai organ. ${ }^{3}$ Secara klinis tampak bahwa bayi jtidak dapat bernapas spontan dan teratur segera setelah lahir. ${ }^{6,7,9}$ Dampak dari keadaan asfiksia tersebut adalah hipoksia, hiperkarbia dan asidemia yang selanjutnya akan meningkatkan pemakaian sumber energi dan menggangu sirkulasi bayi. ${ }^{6,7,9}$

Terdapat beberapa cara dalam menentukan derajat asfiksia bayi. Wayenberg dkk (1998) menggunakan nilai defisit basa pada 30 menit (BD 30) dan penilaian skor neurologik awal, dengan nilai 0-6. ${ }^{10}$ Dikatakan asfiksia berat jika skor logistik >-0.33 (sensitivitas dan spesifisitas $>80 \%) .{ }^{10}$ Skor neurologik awal dapat dilihat pada Tabel $1 .^{10}$

Skor logistik adalah 0,33 x BD30 - 1.06 x skor neurologik awal. ${ }^{11}$ Finner dkk (1981) menyatakan asfiksia berat bila asfiksia pada saat lahir diikuti oleh ensefalopati sedang atau berat. ${ }^{12}$

Kesepakatan di Bagian Ilmu Kesehatan Anak FKUIRSCM adalah bayi yang lahir dengan nilai Apgar menit pertama 0-3 sebagai asfiksia berat dan nilai Apgar menit kedua 4-6 sebagai asfiksia sedang. ${ }^{7}$ Snyder dan Cloherty menyatakan bahwa nilai Apgar 3 atau kurang setelah 5 menit dapat dikatakan adanya asfiksia. Meskipun demikian nilai Apgar yang rendah pada bayi prematur dan bayi masa kecil kehamilan (KMK) bukan merupakan petunjuk asfiksia karena bayi-bayi tersebut cenderung hipotonus, sianosis pada ekstremitas dan lebih lemah. Nilai Agpar 6 atau 7 mungkin sudah maksimal untuk bayi prematur, sedangkan pada bayi dengan masa gestasi kurang dari 30 minggu sering dengan nilai Apgar 2-3, tanpa adanya asfiksia.

Tabel 1. Skor neurologik awal dalam 30 menit pertama kehidupan

\begin{tabular}{lccc}
\hline Penilaian & 2 & 1 & 0 \\
\hline Kesadaran & $\begin{array}{c}\text { Consciousness/ } \\
\text { byperalertness }\end{array}$ & Letargi & Stupor \\
\hline Pernapasan & Teratur & $\begin{array}{c}\text { Tidak } \\
\text { teratur }\end{array}$ & $\begin{array}{c}\text { Tidak } \\
\text { bernapas }\end{array}$ \\
\hline $\begin{array}{l}\text { Reflek Moro } \\
\text { dan pegang }\end{array}$ & $\begin{array}{c}\text { Normal/ } \\
\text { meningkat }\end{array}$ & Berkurang & Tidak ada \\
\hline
\end{tabular}

\section{Faktor risiko}

Pengenalan faktor risiko yang menyertai kelahiran bayi asfiksia memungkinkan dilakukannya persiapan resusitasi sehingga bayi memperoleh terapi yang adekuat saat lahir. ${ }^{7}$ Faktor risiko terjadinya asfiksia pada bayi baru lahir terdiri dari faktor ibu, faktor janin dan faktor persalinan/kelahiran.

Faktor ibu yaitu: infeksi (korioamnionitis), toksemia/eklampsia, penyakit kronik ibu (hipertensi, penyakit jantung, penyakit ginjal, penyakit paru dan diabetes melitus). ${ }^{7}$

Faktor janin yaitu: prematuritas, bayi KMK, gawat janin, bayi kembar, kelainan bawaan, inkompatibilitas golongan darah, dan depresi susunan saraf pusat oleh obat-obatan. $^{7}$

Faktor persalinan kelahiran: polihidramnion, oligohidramnion, perdarahan pranatal (plasenta previa, solutio plasenta), kelainan his, dan kelainan tali pusat (tali pusat menumbung, lilitan tali pusat).

\section{Gangguan fungsi multi organ pada asfiksia berat}

Redistribusi sirkulasi yang ditemukan pada pasien hipoksia dan iskemia akut telah memberikan gambaran yang jelas mengapa terjadi disfungsi berbagai organ tubuh pada bayi asfiksia. ${ }^{1}$ Gangguan fungsi berbagai organ pada bayi asfiksia tergantung pada lamanya asfiksia terjadi dan kecepatan penanganan. ${ }^{13}$ Suatu studi mengenai dampak kerusakan organ pada bayi asfiksia menunjukkan $34 \%$ bayi tidak didapatkan kerusakan organ, 23\% bayi didapatkan kerusakan pada satu organ, 34\% bayi pada dua organ, dan $9 \%$ bayi pada tiga organ. Beberapa peneliti telah melaporkan frekuensi disfungsi berbagai organ vital tersebut yaitu otak, kardiovaskular, paru, ginjal, saluran cerna dan darah. ${ }^{1,3,6,8,14-17}$ Adapun organ vital yang sering terkena adalah ginjal $(50 \%)$, otak (28\%), kardiovaskular $(25 \%)$ dan paru $(23 \%))^{3}$

\section{Dampak sistem susunan saraf pusat}

Ensefalopati hipoksik-iskemik (Gambar1) adalah terminologi yang digunakan untuk menggambarkan kelainan neuropatologis dan klinis yang diperkirakan 
terjadi pada bayi baru lahir akibat asfiksia intrapartum atau masa neonatal. ${ }^{18}$ Ensefalopati hipoksik-iskemik merupakan kelainan neuropatologis yang paling sering ditemukan pada bayi yang mengalami asfiksia, di samping perdarahan periventrikular-intraventrikular yang terutama terjadi pada bayi kurang bulan. ${ }^{18}$ Kelainan neurologis yang dapat ditimbulkan akibat ensefalopati hipoksikiskemik adalah gangguan intelegensia, kejang, gangguan perkembangan psikomotor dan kelainan motorik yang termasuk di dalam palsi serebral. ${ }^{18}$

\section{Patofisiologi}

Gangguan utama pada sel di dalam susunan saraf pusat (SSP) akibat ensefalopati hipoksik-iskemik adalah defisit suplai oksigen yang disebabkan oleh dua hal yaitu hipoksia dan iskemia. ${ }^{2}$ Sumber energi otak adalah oksigen dan glukosa; ${ }^{14,18}$ pada keadaan hipoksemia, glukosa yang masuk ke dalam otak meningkat, glikogenolisis meningkat, glikolisis meningkat, glukosa otak menurun karena pemakaian glukosa lebih banyak dibandingkan glukosa yang masuk, pembentukan asam laktat meningkat $\left(\mathrm{H}^{+}\right)$ karena glikolisis anaerob dan gangguan penggunaan piruvat, ATP menurun, fosforilasi oksidatif menurun. ${ }^{18}$ Pada iskemia, perfusi darah yang masuk ke dalam sebagian atau seluruh otak menurun sehingga glukosa yang masuk ke dalam sel otak menurun, glikogenolisis meningkat, glikolisis meningkat,

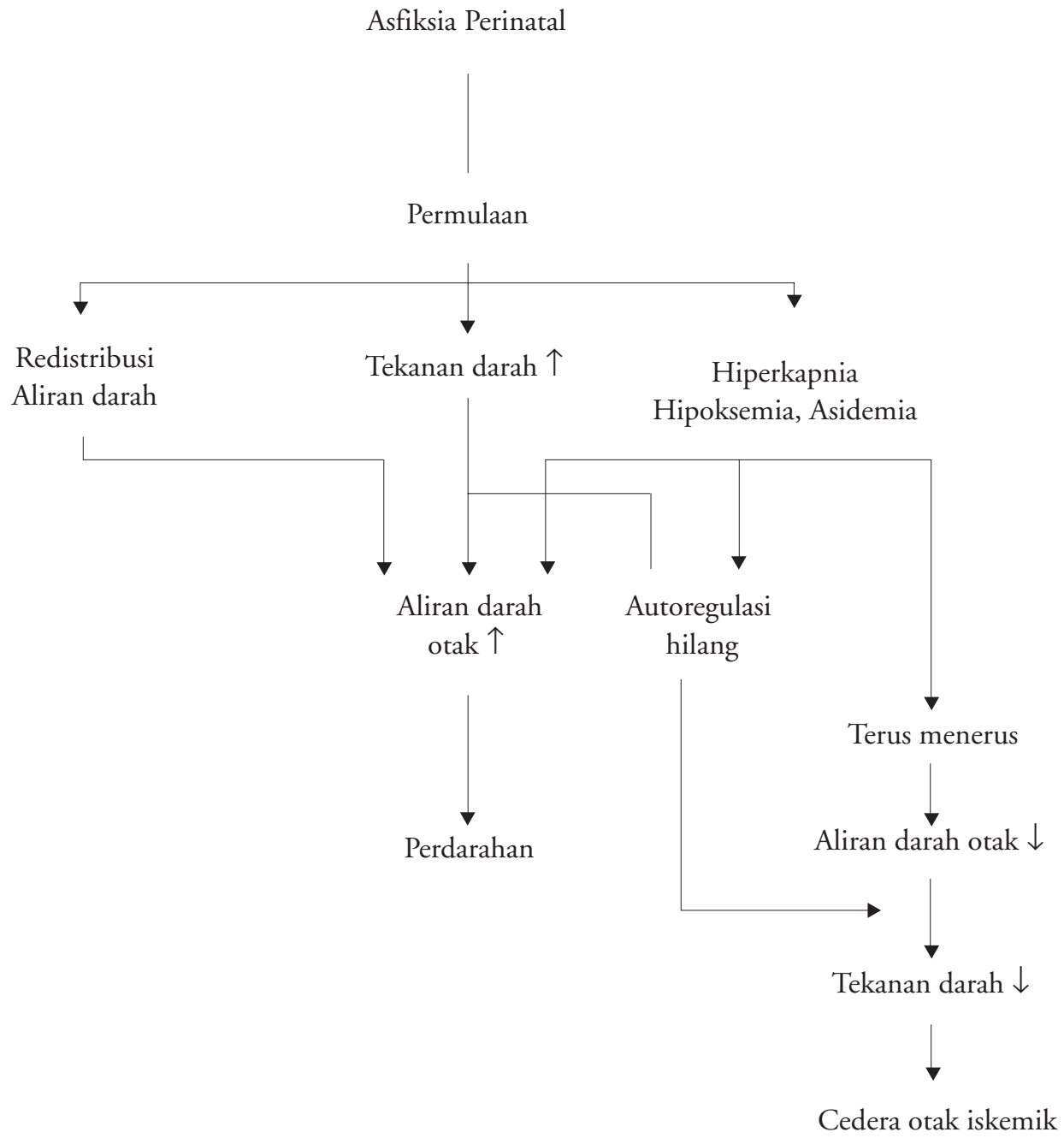

Gambar 1. Hubungan antara asfiksia perinatal dan kelainan otak. ${ }^{18}$ 
pembentukan laktat meningkat menyebabkan asidosis, ATP menurun, akumulasi asam dan no reflux phenomen. ${ }^{19}$

Pada iskemia terjadi gangguan peredaran darah yang menyebabkan pengeluaran laktat terhambat, sehingga $\mathrm{pH}$ lebih cepat menurun dibandingkan dengan hipoksemia. ${ }^{18}$ Juga diperkirakan hipoperfusi otak pasca asfiksia, mengakibatkan konsumsi $\mathrm{O}_{2}$ berkurang pada awal kehidupan neonatus dengan asfiksia berat, yang akan menyebabkan kerusakan sel otak. ${ }^{20}$

Kelainan neurologis akibat ensefalopati hipoksikiskemik tergantung pada distribusi vaskular susunan saraf pusat dan masa gestasi waktu terjadinya gangguan. ${ }^{14,18}$ Bentuk kelainan neuropatologis yang mungkin terjadi adalah nekrosis kortikal multifokal atau fokal, watershed infarct (kerusakan otak parasagital pada bayi cukup bulan dan leukomalasia periventrikular bayi kurang bulan), nekrosis neuron selektif, dan status marmorata (nekrosis ganglia basalis dan nukleus talamus).

\section{Gejala klinis}

Gejala klinis biasanya terjadi 12 jam setelah asfiksia berat yaitu stupor sampai koma, pernafasan periodik atau respiratory effort yang iregular, oligouria, hipotonus, tidak ada refleks komplek seperti Moro dan hisap, kejang tonik-klonik atau multifokal antara 12-24 jam dapat terjadi apnu yang menggambarkan disfungsi batang otak. Dua puluh empat sampai 72 jam kemudian terjadi perburukan, berupa koma, apnu lama dan mati batang otak terjadi 24-72 jam kemudian. ${ }^{3}$

\section{Tata laksana}

Bayi yang mengalami asfiksia akan mengalami gangguan pada berbagai fungsi organ, sehingga penanganannya memerlukan pendekatan multi disiplin. ${ }^{19}$ Penanganan ensefalopati hipoksik-iskemik meliputi upaya mempertahankan suhu tubuh bayi tetap normal, menjaga perfusi dan ventilasi yang baik, mempertahankan kadar glukosa antara 75-100 mg/dl, menjaga keseimbangan asam basa dan elektrolit serta penanganan kejang. ${ }^{3,7,18}$ Diusahakan terapi yang adekuat pada suhu, perfusi, ventilasi, metabolisme glukosa dan kalsium, status asam basa juga pentingnya penanganan kejang. ${ }^{2,3,14}$

\section{Prognosis}

Ekert dkk (1997) meneliti variabel-variabel yang dapat digunakan untuk menentukan kapan neonatus pasca ensefalopati hipoksik-iskemik memerlukan obat-obat neuroprotektif untuk mencegah kecacatan. Variabelvariabel tersebut adalah usia saat bernafas spontan, perlunya kompresi dada, dan usia saat terjadinya kejang. ${ }^{21}$ Disimpulkan jika nafas spontan terjadi $>10$ menit dan kejang yang timbul dalam usia $<4$ jam berhubungan dengan prognosis yang buruk. ${ }^{21}$ Mercuri dkk (2000), melakukan studi dengan menggunakan MRI untuk mengetahui hubungan antara lingkar kepala anak usia 1 tahun dengan riwayat ensefalopati hipoksik-iskemik pada saat neonatus. ${ }^{22}$ Disimpulkan bahwa lingkar kepala yang suboptimal dan mikrosefali sekunder sering terjadi pada anak dengan riwayat ensefalopati hipoksik-iskemik. ${ }^{22}$ Keadaan ini dihubungkan dengan adanya lesi pada masa putih, talamus dan ganglia basalis. ${ }^{22}$ Dianjurkan pengukuran lingkar kepala secara teratur untuk mengetahui kapan terjadinya mikrosefali sekunder. ${ }^{22}$

\section{Dampak sistem kardiovaskular}

Bayi dengan asfiksia perinatal dapat mengalami iskemia miokardial transien. ${ }^{3}$ Secara klinis dapat ditemukan gejala gagal jantung seperti, takipnu, takikardia, pembesaran hati dan irama derap. ${ }^{3,14}$ Bising sistolik dapat terdengar di garis sternalis kiri bawah (regurgitasi trikuspid) dan dapat terdengar di apeks (regurgitasi mitral). ${ }^{3}$ Foto toraks memperlihatkan kardiomiopati dan kongesti vena pulmonalis. ${ }^{3}$ EKG memperlihatkan depresi segmen S-T di mid precordium dan gelombang $\mathrm{T}$ yang negatif abnormal di left precordium. ${ }^{3}$ Serum kreatin kinase plasma $\mathrm{MB}$ isoenzime meningkat $>5$ $10 \%$ mungkin menunjukkan adanya kerusakan miokard. ${ }^{3}$ Ekokardiografi memperlihatkan struktur jantung yang normal tetapi kontraksi ventrikel kiri berkurang terutama di dinding posterior. Selain itu ditemukan hipertensi pulmonal persisten, insufisiensi trikuspid, nekrosis miokardium, dan renjatan. ${ }^{9,23}$

\section{Tata laksana}

Ventilasi yang adekuat untuk mengatasi hipoksemia dan asidosis serta menghindari beban volume yang 
berlebihan. ${ }^{3}$ Perlu pemantauan tekanan darah, tekanan vena sentral, saturasi oksigen dan diuresis. ${ }^{3}$ Jika terjadi syok kardiogenik atasi dengan dopamin atau dobutamin. ${ }^{3}$ Pada kasus berat diperlukan reduksi afterload dengan $\beta$-agonis (isoproterenol), $\alpha$-bloker perifer (fentolamin atau tolazolin), atau nitroprusside. ${ }^{3}$

\section{Prognosis}

Prognosis iskemia miokardium baik. Fungsi jantung akan menjadi normal dalam tiga minggu dan EKG menjadi normal dalam tiga bulan. ${ }^{3}$ Jika terjadi syok kardiogenik yang berat biasanya bayi meninggal karena kerusakan otak dan kerusakan organ vital lainnya. ${ }^{3}$

\section{Dampak terhadap ginjal}

Hipoksia ginjal dapat menimbulkan gangguan perfusi dan dilusi ginjal, serta kelainan filtrasi glomerulus. ${ }^{1} \mathrm{Hal}$ ini timbul karena proses redistribusi aliran darah akan menimbulkan beberapa kelainan ginjal antara lain nekrosis tubulus dan perdarahan medula. ${ }^{13,5}$ Dalam penelitian terhadap 7 orang neonatus dengan asfiksia perinatal, Dauber dkk (1976) menemukan 4 dari 7 orang neonatus dengan gagal ginjal. ${ }^{24}$ Gejala utama oliguria disertai peningkatan blood urea nitrogen (BUN) dan kreatinin. ${ }^{31}$ Gagal ginjal diduga terjadi karena ginjal sangat sensitif terhadap hipoksia. ${ }^{24}$ Hipoksia yang terjadi dalam 24 jam pertama kehidupan akan mengakibatkan iskemia ginjal yang awalnya bersifat sementara namun bila hipoksia berlanjut akan menyebabkan kerusakan korteks dan medula yang bersifat menetap. ${ }^{24}$ Bayi dengan asfiksia mempunyai risiko untuk terjadinya nekrosis tubular akut dan SIADH. ${ }^{3}$ Oleh karena itu perlu dilakukan pemantauan jumlah urin, urinalisis, berat jenis urin, osmolaritas dan elektrolit urin dan serum. ${ }^{3}$ Pengukuran kadar kreatinin urin dan serum bersamaan dengan kadar natrium urin dan serum diperlukan untuk menghitung fraksi ekskresi natrium dan indeks ginjal untuk memastikan adanya gangguan ginjal. ${ }^{3}$ Pengukuran kadar b2mikroglobulin di urin juga berguna untuk mengetahui disfungsi tubulus proksimal ginjal. ${ }^{3}$ Besar ginjal perlu dipantau dengan USG.

Pemberian infus dopamin $1,25-2,5 \mathrm{mg} / \mathrm{kg} / \mathrm{jam}$ (IV) dapat memperbaiki perfusi ginjal. ${ }^{3}$ Jenik dkk melaporkan pemberian teofolin $8 \mathrm{mg} / \mathrm{kgbb}$ yang diberikan beberapa jam setelah lahir pada neonatus cukup bulan dengan asfiksia berat secara bermakna dapat menurunkan kreatinin serum dan b2mikroglobulin urin, serta terjadinya peningkatan klirens kreatinin. ${ }^{25}$

\section{Dampak terhadap saluran cerna}

Bayi asfiksia mempunyai risiko terjadinya iskemia saluran cerna dan enterokolitis nekrotikan (EKN). ${ }^{1,3,7} \mathrm{Hal}$ ini disebabkan pada bayi asfiksia terjadi redistribusi aliran darah ke organ-organ vital. ${ }^{1,3,7}$ Perfusi otak dan jantung dipertahankan dengan mengorbankan ginjal dan usus. ${ }^{26}$

Gejala klinis EKN ada 2 tipe berdasarkan saat timbulnya, yaitu EKN dini dan EKN lambat. ${ }^{26}$ Tipe pertama seringkali terjadi 24-48 jam sesudah lahir. Tipe seperti ini pada umumnya terjadi pada bayi cukup bulan yang sakit berat. ${ }^{26}$ Faktor risiko pada kelompok ini adalah asfiksia neonatorum, gagal nafas, polisitemia dan transfusi tukar. Bayi-bayi ini biasanya belum mendapat makanan enteral. Penyebab EKN dini adalah hipoksikiskemik. Tipe yang kedua terjadinya agak lambat dan terutama pada bayi kurang bulan, yaitu bayi yang telah mendapat makanan enteral. Penyebab EKN tipe ini adalah makanan enteral yang berlebihan dan bakteri tumbuh lampau, sedangkan fungsi intestinal dan daya tahan tubuhnya masih rendah. ${ }^{26}$

Tata laksana EKN adalah dengan tidak memberikan makanan oral, aspirasi cairan lambung, pemberian antibiotik dan nutrisi parenteral. ${ }^{27}$ Operasi dilakukan bila terjadi perforasi atau peritonitis. ${ }^{27}$ Untuk mencegah EKN pada bayi asfiksia adalah pemberian makanan enteral yang isotonik atau hipotonik dengan volume yang kecil dimulai pada hari ke 5-7 atau setelah bising usus normal dan feses tidak berdarah.,

\section{Dampak terhadap hati}

Hati dapat mengalami kerusakan yang berat (shock liver), sehingga fungsinya dapat terganggu. Kadar transaminase serum (SGOT, SGPT), faktor pembekuan (PT, PTT, dan fibrinogen), albumin dan bilirubin harus dipantau. Kadar amoniak serum harus diukur. Diberikan faktor-faktor pembekuan jika diperlukan. Kadar gula darah dipertahankan pada 75$100 \mathrm{mg} / \mathrm{dl}$. Obat-obat yang didetoksifikasi di hati juga harus dimonitor kadarnya secara ketat. ${ }^{3}$ Kegagalan fungsi hati merupakan pertanda prognosis yang buruk. 


\section{Dampak terhadap sistem darah}

Seringkali ditemukan KID akibat rusaknya pembuluh darah, kegagalan hati membuat faktor pembekuan dan sumsum tulang gagal memproduksi trombosit. ${ }^{3}$ Penanganannya meliputi pemantauan Protrombin Time (PT)/Partial Tromboplastin Time (PTT), fibrinogen dan trombosit serta pemberian faktor-faktor pembekuan jika diperlukan. ${ }^{3,6}$

Korst dkk (1996) meneliti 153 neonatus cukup bulan dengan ensefalopati dibandingkan dengan kontrol, dilaporkan hitung sel darah merah berinti pada kelompok neonatus cukup bulan dengan ensefalopati lebih tinggi dibandingkan kelompok kontrol. Diperkirakan peningkatan sel darah merah berinti dapat dipakai sebagai petunjuk saat terjadinya gangguan neurologis pada fetus. ${ }^{28}$ Black well dkk (2000) meneliti hubungan antara jumlah sel darah merah berinti dengan onset terjadinya kejang pada neonatus. Kesimpulan dari penelitian ini mendukung hipotesis kerusakan otak akibat onset kejang terjadi 48- 72 jam sebelum periode intrapartum. ${ }^{29}$ Jazayeri dkk (2000) meneliti kadar eritropoetin pada 203 orang neonatus cukup bulan, 70 di antaranya dengan mekonium pada cairan amnion. Hasil penelitian didapatkan kadar eritropoetin neonatus cukup bulan dengan mekonium pada cairan amnion lebih tinggi dibandingkan kontrol, sehingga keluarnya mekonium dapat dihubungkan dengan kejadian hipoksia fetus kronik. ${ }^{30}$

\section{Dampak terhadap paru}

Dampak asfiksia terhadap paru adalah hipertensi pulmonal persisten, mekanisme terjadinya adalah vasokonstriksi paru akibat hipoksia dan asidosis, pembentukan otot arteriol paru pada masa pranatal, pelepasan zat aktif seperti leukotrin dan pembentukan mikrotrombus; ${ }^{27}$ perdarahan paru, edem paru karena gagal jantung, acute respiratory distress syndrome, HMD sekunder akibat gangguan produksi surfaktan karena asfiksia, dan aspirasi mekonium. ${ }^{27}$ Pengobatan berupa oksigenasi dan ventilasi yang adekuat. ${ }^{3}$

\section{Daftar Pustaka}

1. Aminullah A. Konsekuensi kelainan sistemik berbagai organ tubuh akibat hipoksia dan iskemia neonatus. Dalam:
Suradi R, Monintja HE, Amalia P, Kusumowardhani D, penyunting. Penanganan mutakhir bayi prematur: memenuhi kebutuhan bayi prematur untuk menunjang peningkatan kualitas sumber daya manusia. Naskah Lengkap Pendidikan Kedokteran Berkelanjutan Ilmu Kesehatan Anak FKUI XXXVIII. FKUI; 1997 7-8 April; Jakarta: Balai Penerbit FKUI; 1997. h. 165-84.

2. Urgander U, Erikkson M, Zetterstrom R. Severe neonatal asphyxia incidence and prediction of outcome in the Stockhlom area. Acta Paediatr Scand 1983; 72:321-5.

3. Snyder EY, Cloherty JP. Perinatal asphyxia. Dalam: Cloherty JP, Stark AR, penyunting. Manual of neonatal care. Edisi ke-4. Philadelphia: Williams \& Wilkins; 1998. h. 515-33.

4. Alisjahbana A, Hidayat S, Mintardaningsih, Primardi A, Harliany E, Sofiatin Y, dkk. Management of birth asphyxia at home and health center. Paediatr Indones 1999; 39:88-101.

5. Data Ilmu Kesehatan Anak FKUI-RSCM pada tahun 2000.

6. Gomella TL, Cunningham D, Eyal FG. Neonatology management, procedures, on-call problems, diseases, drugs. Edisi ke-2. Connecticut: Lange; 1992. h. 391-9.

7. Aminullah A. Asfiksia bayi baru lahir. Dalam: Markum AH, Ismael S, Alatas H, Akib A, Firmansyah A, Sastroasmoro S, penyunting. Buku Ajar Ilmu Kesehatan Anak. Jakarta: Fakultas Kedokteran Universitas Indonesia; 1991. h. 261-5.

8. Indarso F. Dampak jangka panjang bayi asfiksia. Disampaikan pada Kongres Nasional Ilmu Kesehatan Anak XI, Jakarta, 4-7 Juli, 1999. h. 547-57.

9. Thorp JA. What is birth asphyxia ? Am J Obstet Gynecol 1990; 163:1367-8.

10. Wayenberg JL, Dramaix N, Vermeylen D, Bormans J, Pardou A. Neonatal out come after birth asphyxia: early indicators of prognosis. Prenat Neonat Med 1998; 3:4829.

11. Kliegman RM, Behrman RE. Hypoxia-ischemia. Dalam: Behrman RE, Kliegman RM, Nelson WE, Vaughan III VC, penyunting. Nelson textbook of pediatrics. Edisi ke-14. Philadelphia: Saunders; 1992. h. 458-9.

12. Finner NN, Robertson CM, Richards RT, Pinnel LE, Peters KL. Hypoxic-ischemic enchephalopathy in term neonates: perinatal factors and outcome. J Pediatr 1981; 98:112-7.

13. Roberton NRC. A manual of neonatal intensive care. Edisi ke-3. Cambridge: Edward Arnold; 1993. h. 72-6.

14. Glucman PD, Tan W, Mallard C, Williamms CE. Pathophysiology of perinatal asphyxia. Dalam: Shankaran S, penyunting. Clinics in perinatology perinatal asphyxia. Philadelphia: Saunders; 1993. h. 305-26.

15. Low JA, Panagiotopoulos C, Derrick J. Newborn complications after intrapartum asphyxia with metabolic acidosis in the term fetus. Am J Obstet Gynecol 1994; 170:1081-7.

16. Portman RJ, Carter BS, Gaylord MS, Murphy MG, Thieme RE, Merenstein. Predicting neonatal morbidity after perinatal asphyxia: A scoring System. Am J Obstet Gynecol 1990; 162:174-82. 
17. MacDonald HM, Mulligan JC, Allen AC, Taylor PM. Neonatal asphyxia I. Relationship of obstetric and neonatal complication to neonatal mortality in 38,405 consecutive deliveries. J Pediatr 1980; 96:898-902.

18. Pryds O, Greisen G, Lou H, Friis-Hansen B. Vasoparalysis associated with brain damage in asphysiated term infants. J Pediatr 1990; 117:119-25.

19. Shadid M, Moison R, Steendijk P, Hiltermann L, Berger HM, Van Bel F. The effect of antioxidative combination therapy on post hypoxic-ischemic perfusion, metabolism, and electrical activity of the newborn brain. Pediatric Resp 1998; 44:119-24. [Abstr]

20. Van Bel F, Dorrepaal CA, Benders MJNL, Zeeuwe PEM, Van de Bor M, Berger HM. Changes in cerebral hemodynamics and oxygenation in the first 24 hours after birth asphyxia. Pediatrics 1993; 92:365-72.

21. Ekert P, Perlman M, Steinlin M, Hao Y. Predicting the outcome of postasphyxial hypoxic-ischemic encephalopathy within 4 hours of birth. J Pediatr 1997; 13:613-7.

22. Mercuri E, Ricci D, Cowan FM, Lessing D, Frisone MF, Hataja J, dkk. Head growth infants with hypoxic-ischemic encephalopathy: correlation with neonatal magnetic resonance imaging. Pediatric 2000; 106:235-43.

23. Primhak RA, Jedeikin R, Ellis G, Makela SK, Gillan JE, Swyr PR, dkk. Myocardial ischaemia in asphyxia neona- torum. Acta Pediatr Scand 1985; 74:595-600.

24. Dauber IM, Krauss AM, Symchych PS, Aula PAM. Renal failure following perinatal anoxia. J Pediatr 1976; 88:851-5.

25. Jenik AG, Cernadas JMC, Gorenstein A, Ramirez JA, Vain M, Armadans M, dkk. A randomized, double blind, placebo-controlled trial of the effects of prophylatic theophylline on renal function in term neonates with perinatal asphyxia. Electronic abstract http://www.pediatrics.org.

26. Yu VHY, Monintja HE. Enterokolitis nekrotikans. Dalam: Beberapa masalah perawatan intensif neonatus. Jakarta: BP FKUI; 1997. h. 155-86.

27. Yu VHY, Monintja HE. Asfiksia perinatal. Dalam: Beberapa masalah perawatan intensif neonatus. Jakarta: BP FKUI; 1997. h. 129-51.

28. Korst LM, Phelan JP, Ahn MO, Martin GI. Nucleated red blood cells: an update on the marker for fetal asphyxia. Am J Obstet Gynecol 1996; 175:843-6.

29. Blackwell SC, Refuerzo JS, Wolfe HM, Hassan SS, Berry SM, Sokol RJ, dkk. The relationship between nucleated red blood cell counts and early-onset neonatal seizures. Am J Obstet Gynecol 2000; 182:1452-7.

30. Jazayeri A, Politz L, Tsibris JCM, Queen T, Spellacy WN. Fetal erythropoeitin levels in pregnancies complicated by meconium passage: does meconium suggest fetal hypoxia ?. Am J Obstet Gynecol 2000; 183:188-90. 